\title{
Integration of an Objective Approach Focused on the Consumer to Evaluate the Quality of Processed Brussels Sprouts
}

\author{
Daniela Flavia Olivera ${ }^{1,2}$, Sonia Zulma Viña ${ }^{1}$, Ricardo Mario Ferreyra ${ }^{1}$, Alicia Mugridge ${ }^{1}$, \\ Rodolfo Horacio Mascheroni ${ }^{1,2}$, Alicia Raquel Chaves ${ }^{1}$
}

${ }^{1}$ CIDCA (Centro de Investigación y Desarrollo en Criotecnología de Alimentos), CONICET La Plata, Universidad Nacional de La Plata (UNLP), La Plata, Argentina; ${ }^{2}$ MODIAL (Unidad de Investigación y Desarrollo en Modelado y Diseño en Ingeniería de Alimentos), Facultad de Ingeniería, Universidad Nacional de La Plata (UNLP), La Plata, Argentina.

Email: arch@quimica.unlp.edu.ar

Received June 15 ${ }^{\text {th }}, 2011$; revised August $24^{\text {th }}, 2011$; accepted September $3^{\text {rd }}, 2011$.

\begin{abstract}
Few research works focus on integration of the objective analysis of frozen vegetable quality and the preference of consumers for these products. The aim of the present work was to investigate the consumption patterns of Brussels sprouts, the degree of importance that consumers give to main attributes, and the constructions they make about product quality. For this aim, a series of surveys (snowball sampling method) were performed with consumers from four cities in Argentina. Also, the effect of different industrial operations (two blanching procedures, freezing and cooking) on texture, color, total chlorophyll content and ascorbic acid content of processed sprouts, was determined with respect to the fresh product. A function $Z$ (overall quality) was defined to integrate the information obtained by both approaches. Taking into account the relative importance assigned by surveyed consumers to appearance, texture and nutrient content, the quality of final product obtained from different processing methods was equivalent. Most consumers, $96 \%$ of total, preferred the fresh product, which suggests that prejudging by consumers influences attempts at objective estimation of quality.
\end{abstract}

Keywords: Frozen Vegetables, Brassica oleracea L. Gemmifera, Quality Attributes, Quality Perception

\section{Introduction}

The relationship between vegetables consumption and risk reduction of chronic diseases is well known by the scientific community [1-3]. Vegetables from the genus Brassica may be beneficial in preventing such diseases [4], since besides vitamins, carotenoids and polyphenols, they contain glucosinolates, which are compounds with low antioxidant activity but their hydrolysis generates products with certain anti-carcinogenic properties [5-7]. The main hydrosoluble antioxidants that vegetable tissues contain are vitamin $\mathrm{C}$ and phenolic compounds. Vitamin $\mathrm{C}$ includes the ascorbic acid and its oxidation product, the dehydroascorbic acid, which are present in high concentration in Brussels sprouts (Brassica oleracea L. gemmifera $\mathrm{DC}$ ). For this reason, their incorporation to diet in higher amounts or the increase in the consumption frequency would be helpful to human health.
Despite of the evidence, campaigns promoting vegetables consumption, either fresh or frozen, have not been effective, at least in developing countries. The factors that influence the consumption of vegetables are personal (taste preference, attitude about health and body care), related to living and eating habits (frequency and type of consumed foods, environment of consumption), and of socio-environmental nature (choice of healthy eating, parental or familiar eating habits, socio-economic status, home availability of such foods, etc.) [8]. There are studies about the changes in quality and nutritional value of vegetables induced by freezing, conventional blanching and cooking [9-11], as well as specific information of the Brassica vegetables $[4,12,13]$.

According to Viteri [14], frozen vegetables are characterized globally by keeping the image of safety, healthy and easy-to-consume products, adaptable to consumers' needs. They maintain the quality of the fresh 
product due to the short time existing between harvest and industrial processing, and reduce notably the amount of waste, facilitating the consumption of small portions. In Argentina, the annual average consumption of frozen vegetables per individual is $250 \mathrm{~g}$ [14], and it is considered as relatively low and corresponds to part-fried potatoes mainly. The consumption of Brussels sprouts is nearly limited to the fresh product, with a marked seasonal component. It is feasible that locally, in contrast with developed countries, there exists a paradigm in consumers that gives a lower quality to processed products than to the fresh ones. For this reason, it is important to evaluate the different operations that affect the main quality attributes, and simultaneously how such attributes are assessed by consumers. Therefore, the objectives of the present work were: 1) to investigate about the consumption habits of Brussels sprouts, the importance degree that consumers give to main attributes, and the construction they make about the product quality; 2) to determine how the different industrial operations affect the quality of Brussels sprouts; 3 ) to integrate the information obtained by both approaches.

\section{Materials and Methods}

\subsection{Surveys to Consumers}

To evaluate the buying behaviour of Brussels sprouts, a first survey was done to 92 habitual consumers of vegetables, within the range of 25 - 65 years-old, from four cities of Argentina (Ciudad Autónoma de Buenos Aires, La Plata-Buenos Aires, Córdoba-Córdoba, Rosario-Santa $\mathrm{Fe}$ ), which were chosen since they are urban centres with more than 500,000 habitants. The snowball sampling method was applied to perform the surveys $[15,16]$. Data was obtained between August and December in 2009, asking about the buying and consumption frequency, preference and reason of preference.

From this first experience, habitual consumers of Brussels sprouts were selected, recruiting those consuming this vegetable at least once a month or seasonably. A second survey was carried out with these people; it was assessed the importance given to appearance, consistence and nutrients content of Brussels sprouts at the moment of consumption. For this aim, a Likert scale was used to measure each attribute.

\subsection{Instrumental Analyses}

\subsubsection{Vegetable Samples}

Brussels sprouts (Brassica oleracea L. gemmifera DC) cultivar Oliver were used, which were produced in a farm located in the agricultural belt of La Plata $\left(34^{\circ} 59^{\prime}\right.$ SL; 58 $30^{\prime} \mathrm{WL}$ ), Argentina. Immediately after harvest, external leaves were eliminated and sprouts were selected according to a uniform commercial size [17].

\subsubsection{Processing Operations}

With the aim of assessing instrumentally how the processing affected the main physicochemical attributes that contribute to quality of Brussels sprouts, the following operations were performed to fresh samples: two blanching treatments, one cooking method, and one freezing procedure; which were evaluated and selected previously $[17,18]$. The operating conditions of different performed processes are informed in Table 1.

\subsubsection{Instrumental Measurements}

\subsubsection{Texture}

Texture measurement (compression test) was carried out in a texture analyzer TA.XT2i (Stable Micro Systems Ltd, Surrey, UK) fitted with an aluminium disc of $75 \mathrm{~mm}$ diameter (probe P/75). Assays were performed at velocity $1 \mathrm{~mm} \cdot \mathrm{s}^{-1}$, compressing $3 \mathrm{~mm}$ the product. For each treatment 10 replicates were used. Data was processed using the software Texture Expert ${ }^{\circledR}$ Exceed v 1.0 (Stable Micro Systems). Firmness (N) was calculated as the maximum force peak [19].

\subsubsection{Color}

Color was measured using a colorimeter Minolta CR 300 Series (Osaka, Japan). The device was calibrated against a standard white plate $(\mathrm{Y}=93.2 ; \mathrm{x}=0.3133 ; \mathrm{y}=0.3192)$. Color was registered at three different positions of sprouts head. For each treatment 10 replicates were used.

\subsubsection{Chemical Analyses}

\subsubsection{Chlorophyll}

Total chlorophyll content was determined by spectrophotometry according to the method proposed by Lichtenthaler [20], using acetone $80 \% \mathrm{v} / \mathrm{v}$ for the pigment

Table 1. Details about different operations applied to Brussels sprouts.

\begin{tabular}{|c|c|c|c|c|}
\hline Operation & Blanching & Microwave blanching & Cooking & Freezing \\
\hline Condition & $\begin{aligned} & \text { Water immersion at } 50^{\circ} \mathrm{C} \\
+ & \text { Water immersion at } 98^{\circ} \mathrm{C}\end{aligned}$ & $\begin{aligned} & \text { Microwave at } 700 \mathrm{~W} \\
+ & \text { Water immersion at } 98^{\circ} \mathrm{C}\end{aligned}$ & Water immersion at $98^{\circ} \mathrm{C}$ & Cryogenic freezer at $-40^{\circ} \mathrm{C}$ \\
\hline Time & $5 \min +3 \min$ & $5 \min +2 \min$ & $7 \mathrm{~min}$ & $\begin{array}{l}\text { Until reaching }-18^{\circ} \mathrm{C} \text { at the } \\
\text { thermal centre }\end{array}$ \\
\hline
\end{tabular}


extraction. Absorbance was recorded at $646.8 \mathrm{~nm}$ and $663.2 \mathrm{~nm}$. Extractions and measurements were done by duplicate. Results were expressed as $\mu \mathrm{g}$ per $\mathrm{g}$ of fresh matter.

\subsubsection{Ascorbic Acid}

Ascorbic acid content was quantified by high performance liquid chromatography according to Wimalasiri et al. [21], with slight modifications [17,18]. Identification and quantification were performed using a standard solution of ascorbic acid. Extractions and measurements were done by duplicate. Results were informed as mg per 100 $\mathrm{g}$ of fresh matter.

\subsubsection{Overall Quality}

To quantify the change in overall quality produced by each operation, a function $\mathrm{Z}$ was defined using an additive model, which is one of the most popular approaches in consumers' preference studies [22].

In this way, overall quality was established as a function of the consumer opinion about the three main attributes of the product, i.e. appearance, consistency and nutrients content, and the instrumental measurement or chemical analysis related to such attributes. Then, $\mathrm{Z}$ was expressed as following:

$$
Z=a F+b C+c N
$$

where $F, C$ and $N$ are the retention percentages of firmness, color and nutrients, respectively; $\mathrm{a}, \mathrm{b}$ and $\mathrm{c}$ are the coefficients (weight factors) determined as a function of consumer response associated with each attribute.

\subsubsection{Statistical Analysis}

An analysis of variance of the obtained data was performed. Mean comparison was done using the least significant difference test (Fisher's test) with $p<0.05$.

\section{Results and Discussion}

\subsection{Surveys}

Figure 1 shows the results regarding the consumption frequency of Brussels sprouts. It can be seen that more than $42 \%$ of surveyed people consume the product seasonably. From this fact, it can be inferred a high preference for the fresh product, which was reflected also in the answers to third and fourth questions of the first survey, where more than $90 \%$ of respondents turned to this option. The main indicated motivation was the image of the non processing products, being associated with higher quality levels.

With respect to seasonably consumption, it resulted to be relatively frequent, since the highest percentage of respondents corresponded to consumption made at least once a week (Figure 1).

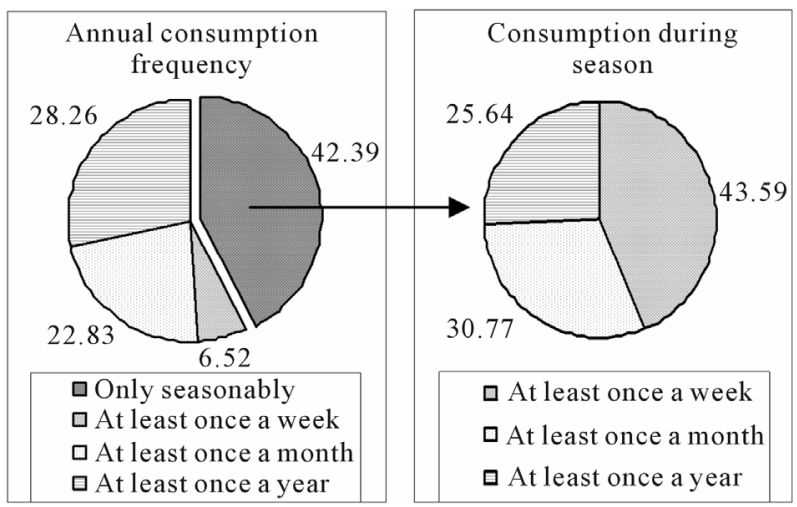

Figure 1. Consumption frequency (\%) of Brussels sprouts.

Regarding the second survey, habitual consumers assigned $36 \%, 35 \%$ and $29 \%$ of relative importance to appearance, consistency and nutritional value parameters, respectively. These results indicate that a sort of parity would exist between the mentioned attributes, as components of the global quality idea the consumers construct about them.

In a qualitative study, Zeinstra et al. [23] evaluated the perceptions of certain groups of children about fruits and vegetables. Participants were asked about which were the most disliked foods, and several respondents indicated vegetables, and particularly, Brussels sprouts. Besides, when asked about the reasons for the like or dislike of such foods, the main attributes mentioned were texture, taste and preference.

\subsection{Instrumental Measurements}

Firmness values of Brussels sprouts submitted to different treatments are shown in Figure 2. Both blanching operations produced a significant decrease of firmness (greater than $80 \%$ ), without observing significant differences between them. Cooking the product did not induce any significant change in the texture with respect to both blanching alternatives, but the incorporation of freezing prior to cooking produced an additional loss of firmness.

Gonçalves et al. [24] reported similar results about the firmness of pumpkin, which decreased $86 \%$ after blanching in water at $75^{\circ} \mathrm{C}-95^{\circ} \mathrm{C}$. This is because thermal treatments strongly affect vegetables tissues, since they produce the solubilization of pectins present in the plant cell wall matrix [25]. Moreover, the temperature-jump generates the rupture of membrane cells, which allows the diffusion of water and solutes, as well as the loss of turgidity [26]. Even others components that contribute to insoluble fibre, such as cellulose, are also affected by hot water-immersion treatments.

The additional firmness loss due to freezing is produced when several factors that cause texture degradation 


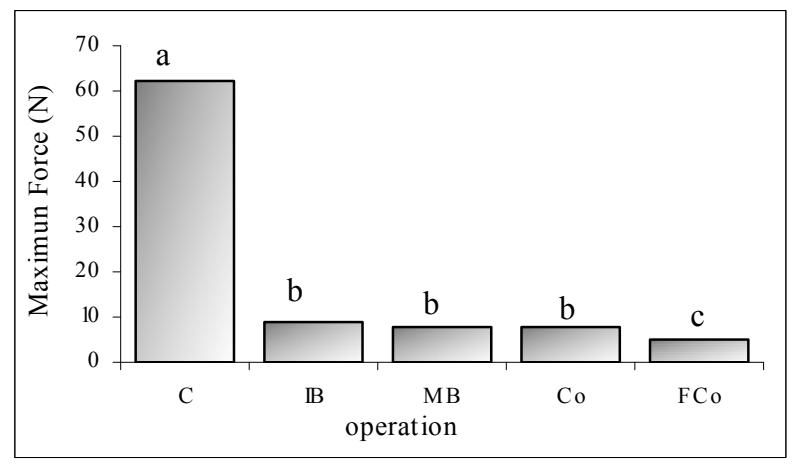

Figure 2. Texture of fresh and processed Brussels sprouts. $\mathrm{C}=$ control (fresh product); IB = immersion blanching; $\mathrm{MB}$ $=$ microwave blanching; $\mathrm{Co}=$ cooking; $\mathrm{FCo}=$ freezing and cooking. Different letters indicate significant differences $(p$ $\leq 0.05$ ) between operations.

converge, which are related to changes in cell membranes, cytoplasmic content, cell wall and middle lamella. During freezing ice is formed especially in the extracellular space, generating a water activity gradient from the inner ambient cell towards the exterior. These changes can result in the denaturation of proteins, alteration of plasma membranes and organelles.

Results regarding color measurement of Brussels sprouts surface are shown in Figures 3 and 4 . The observed differences were registered for $\mathrm{L}^{*}$ coordinate and the chroma value. No significant variations were observed in the hue angle. With respect to $L^{*}$ coordinate (Figure 3), all tested methods caused a loss of the product lightness. Chroma values of Brussels sprouts (Figure 4) were affected mainly by cooking operation, which produced the most significant decreases $(p<0.05)$ regarding the color saturation.

Intensity of green color can be attributed to chlorophyll content, and it is important in the determination of final quality of these products [27].

Results of the analysis of total chlorophyll in Brussels sprouts are depicted in Table 2. The performed operations did not cause significant differences in samples, under the tested conditions. Therefore, from an alimentary point of view, the processes implemented in this work would allow preserving the content of total chlorophyll. This fact is of utmost importance during processing of green vegetables since exists evidence of antimutagenic and anticarcinogenic activity, and antitumour action of chlorophyll and its derivatives, besides contributing to color [28-30].

Regarding ascorbic acid content, Sikora et al. [13] reported that the average concentration of vitamin $\mathrm{C}$ in Brussels sprouts is $90.3 \mathrm{mg} 100 \mathrm{~g}^{-1}$, which is in agreement with the results of the present work (Table 2).

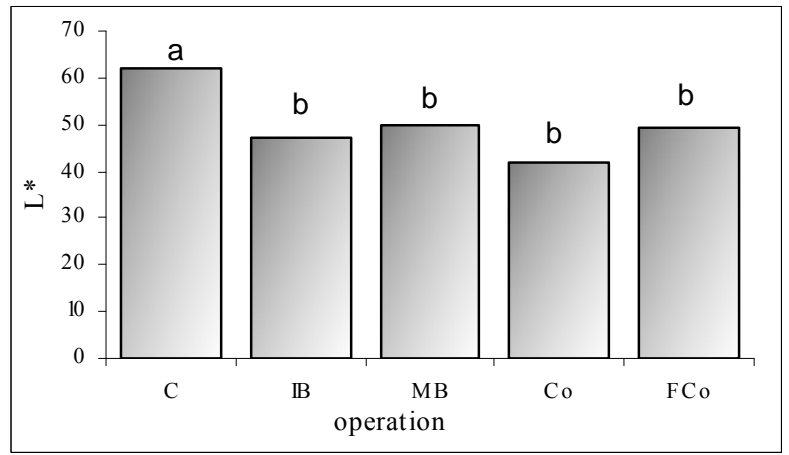

Figure 3. Lightness $\left(L^{*}\right)$ of fresh and processed Brussels sprouts. $\mathrm{C}=$ control (fresh product); $\mathrm{IB}=$ immersion blanching; $\mathrm{MB}=$ microwave blanching; $\mathrm{Co}=$ cooking; $\mathrm{FCo}$ $=$ freezing and cooking. Different letters indicate significant differences $(p \leq 0.05)$ between operations.

Table 2. Total chlorophyll and ascorbic acid contents of fresh and processed Brussels sprouts.

\begin{tabular}{ccc}
\hline Operation & $\begin{array}{c}\text { Total chlorophyll } \\
(\mu \mathrm{g} / \mathrm{g} \text { fresh matter })\end{array}$ & $\begin{array}{c}\text { Ascorbic acid } \\
(\mathrm{mg} / 100 \mathrm{~g} \text { fresh matter })\end{array}$ \\
\hline C & $31.83^{\mathrm{a}}$ & $89.03^{\mathrm{a}}$ \\
IB & $23.21^{\mathrm{a}}$ & $72.12^{\mathrm{b}}$ \\
MB & $29.36^{\mathrm{a}}$ & $71.86^{\mathrm{b}}$ \\
Co & $28.17^{\mathrm{a}}$ & $77.32^{\mathrm{b}}$ \\
FCo & $34.44^{\mathrm{a}}$ & $93.12^{\mathrm{a}}$ \\
\hline
\end{tabular}

$\mathrm{C}=$ control (fresh product); $\mathrm{IB}=$ immersion blanching; $\mathrm{MB}=$ microwave blanching; $\mathrm{Co}=$ cooking; $\mathrm{FCo}=$ freezing and cooking. Different letters indicate significant differences $(p \leq 0.05)$ between operations.

Other authors informed that the content of vitamin $\mathrm{C}$ in Brussels sprouts is in the range of $66-196 \mathrm{mg} 100 \mathrm{~g}^{-1}$ [31]. As can be seen in Table 2, blanching and cooking operations caused a significant decrease $(p<0.05)$ in the ascorbic acid concentration.

Sikora et al. [13] carried out a similar study on several Crucifera vegetables, assessing their antioxidant activity during water-immersion heating. Authors found that the applied technological processes reduced the vitamin $\mathrm{C}$ content in the samples. The minor loss was caused by blanching. Cooking in boiling water produced the major decrease in vitamin $\mathrm{C}$ level of the studied products.

Thermal processing would affect the ascorbic acid content in a higher degree than other operations; Castro et al. [32] assessed alternative treatments and informed that high pressure treatments applied to pepper cause a lesser reduction of ascorbic acid content than conventional blanching.

\subsection{Overall Quality}

From (1) and the values that surveyed habitual consum- 


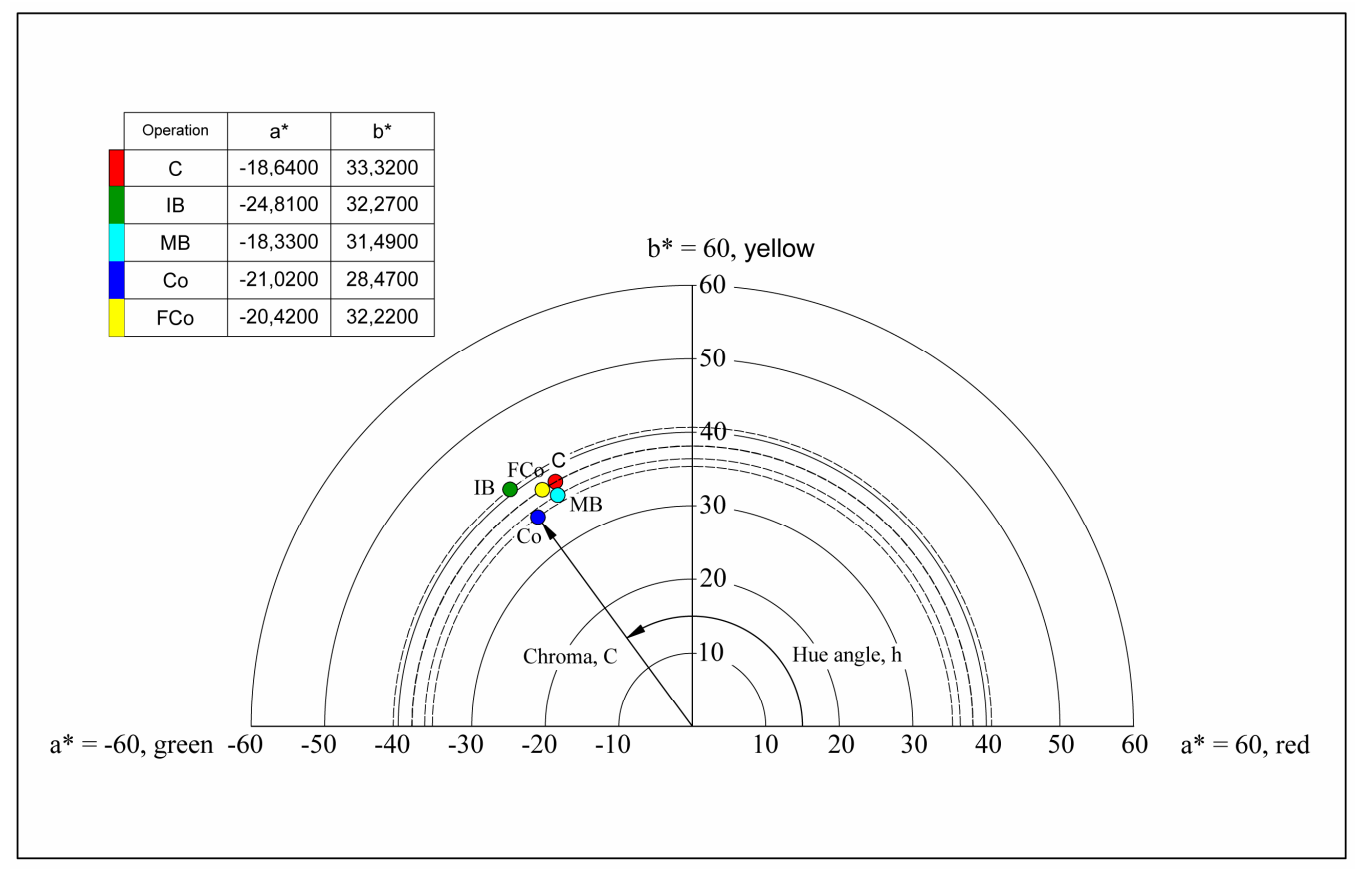

Figure 4. Chroma and Hue values of fresh and processed Brussels sprouts. $\mathrm{C}=$ control (fresh product); IB $=$ immersion blanching; $\mathrm{MB}=$ microwave blanching; $\mathrm{Co}=$ cooking; $\mathrm{FCo}=$ freezing and cooking.

ers assigned to the importance they attributed to variables: appearance, consistency and nutritional value, overall quality was expressed as:

$$
Z=0.36 F+0.35 C+0.29 N
$$

By means of (2) and instrumental measurements that allowed calculating percentage of firmness (F), color (C) and nutrients content $(\mathrm{N})$, the overall quality of the product obtained under different operations was quantified. It is worth to note that in (2), the values of $\mathrm{C}$ were determined from the $\mathrm{L}^{*}$ coordinate percentages because, regarding color, it was the parameter that presented the higher variations for the different applied operations. In the case of nutrients content $(\mathrm{N})$, it was considered the percentage of ascorbic acid retention, since Viña et al. [17] and Olivera et al. [18] did not report significant differences for other assessed compounds, such as flavonoids (antioxidants).

Values of $Z$ for each operation are presented in Figure 5.

From this data it can be inferred that both blanching and cooking operations presented similar deterioration percentages of overall quality of Brussels sprouts. On the other hand, the freezing process did not involve further losses in addition to the ones caused by cooking.

\section{Conclusions}

The different processing methods applied to Brussels

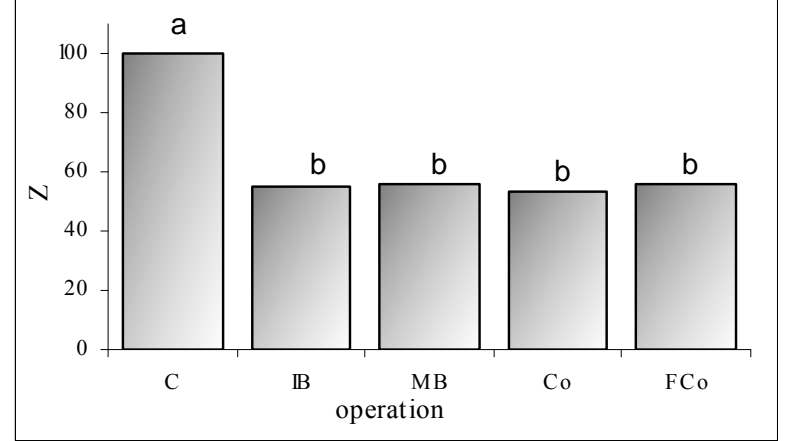

Figure 5. Overall quality (\%) of fresh and processed Brussels sprouts. $C=$ control (fresh product); $I B=$ immersion blanching; $\mathrm{MB}=$ microwave blanching; $\mathrm{Co}=$ cooking; FCo $=$ freezing and cooking. Different letters indicate significant differences $(p \leq 0.05)$ between operations.

sprouts lead to final products with equivalent quality, according to relative importance assigned to different attributes by surveyed consumers. It was even observed that the frozen product obtained quality levels slightly higher than other alternatives. Nevertheless, when the same consumers were asked about their preferences, they answered in favor of acquiring fresh products, which means that there exist prejudging acts or paradigms on objective evaluation at the moment of deciding the consumption of this type of food.

The obtained information from this kind of studies 
could be useful for the design of campaigns with the aim of promoting the consumption of frozen vegetables, especially those having a marked seasonal production, such as Brussels sprouts.

\section{Acknowledgements}

Authors thank the financial support given by Consejo Nacional de Investigaciones Científicas y Técnicas (CONICET), UNLP and Agencia Nacional de Promoción Científica y Tecnológica (ANPCyT), from Argentina.

\section{REFERENCES}

[1] P. M. Kris-Etherton, K. D. Hecker, A. Bonanome, S. M. Coval, A. E. Binkoski, K. F. Hilpert, A. E. Griel and T. D. Etherton, "Bioactive Compounds in Foods: Their Role in the Prevention of Cardiovascular Disease and Cancer," American Journal of Medicine, Vol. 113 No. 9B, 2002, pp. 71S-88S. doi:10.1016/S0002-9343(01)00995-0

[2] C. B. Ambrosone, S. E. Mc Cann, J. L. Freudenheim, J. R. Marshall, Y. Zhang and P. G. Shields, "Breast Cancer Risk in Premenopausal Women is Inversely Associated with Consumption of Broccoli, a Source of Isothiocyanates, but is Not Modified by GST Genotype," Journal of Nutrition, Vol. 134, No 6, 2004, pp. 1134-1138.

[3] C. A. Thomson, T. R. Newton, E. J. Graver, K. A. Jackson, P. M. Reid, V. L. Hartz, E. C. Cussler and I. A. Hakim, "Cruciferous Vegetable Intake Questionnaire Improves Cruciferous Vegetable Intake Estimates," Journal of the American Dietetic Association, Vol. 107, No 4, 2007, pp. 631-643. doi:10.1016/j.jada.2007.01.016

[4] Z. Lisiewska, W. Kmiecik and A. Korus, "The Amino Acid Composition of Kale (Brassica oleracea L. var. acephala), Fresh and after Culinary and Technological Processing," Food Chemistry, Vol. 108, No. 2, 2008, pp. 642-648. doi:10.1016/i.foodchem.2007.11.030

[5] M. Paolini, "Brussels Sprouts: An Exceptionally Rich Source of Ambiguity for Anticancer Strategies," Toxicology and Applied Pharmacology, Vol. 152, No. 2, 1998, pp. 293-294. doi:10.1006/taap.1998.8517

[6] Y.-S. Keum, W.-S. Jeong and A. N. T. Kong, "Chemoprevention by Isothiocyanates and Their Underlying Molecular Signaling Mechanisms," Mutation Research, Vol. 555, No. 1-2, 2004, pp. 191-202. doi:10.1016/j.mrfmmm.2004.05.024

[7] A. Podsędek, "Natural Antioxidants and Antioxidant Capacity of Brassica Vegetables: A Review," LWT-Food Science and Technology, Vol. 40, No. 1, 2007, pp. 1-11.

[8] A. Tudoran, S. O. Olsen and D. C. Dopico, "The Effect of Health Benefit Information on Consumers Health Value, Attitudes and Intentions," Appetite, Vol. 52, No. 3, 2009, pp. 568-579. doi:10.1016/j.appet.2009.01.009

[9] C.-H. Lin and C.-Y. Chang, "Textural Change and Antioxidant Properties of Broccoli under Different Cooking Treatments," Food Chemistry, Vol. 90, No. 1-2, 2005, pp. 9-15. doi:10.1016/j.foodchem.2004.02.053
[10] N. Turkmen, F. Sari and Y. S. Velioglu, "The Effect of Cooking Methods on Total Phenolics and Antioxidant Activity of Selected Green Vegetables," Food Chemistry, Vol. 93, No. 4, 2005, pp. 713-718. doi:10.1016/j.foodchem.2004.12.038

[11] W. Canet and M. D. Alvarez Torres, "Quality and Safety of Frozen Vegetables,” In: D.-W. Sun, Ed., Handbook of Frozen Food Processing and Packaging, CRC Press, Boca Raton, 2006, p. 377.

[12] P. Gębczyński and W. Kmiecik, "Effects of Traditional and Modified Technology, in the Production of Frozen Cauliflower, on the Contents of Selected Antioxidative Compounds," Food Chemistry, Vol. 101, No. 1, 2007, pp. 229-235. doi:10.1016/j.foodchem.2006.01.021

[13] E. Sikora, E. Cieślik, T. Leszczyńska, A. Filipiak-Florkiewicz and P. M. Pisulewski, "The Antioxidant Activity of Selected Cruciferous Vegetables Subjected to Aquathermal Processing," Food Chemistry, Vol. 107, No. 1, 2008, pp. 55-59. doi:10.1016/j.foodchem.2007.07.023

[14] L. Viteri, "Hortalizas Congeladas, “(Doc A-14) Estudio 1 EG 33.7, Componente A; BID 925/OC-AR. CEPAL Office-UN in Buenos Aires Economicai Police Office, Nation Economy Minister, 2003, Argentina. Available at: http://www.eclac.org/argentina/noticias/paginas/7/12267/I nforme33714A.PDF

[15] A. Fernández-Nogales, "Investigación y Técnicas de Mercado," 2da Edición, Esic Editoral, Madrid, 2004, pp. 154155.

[16] I. Grande and E. Abascal, “Análisis de Encuestas," Esic Editorial. Madrid, 2005, pp. 69-70.

[17] S. Z. Viña, D. F. Olivera, C. M. Marani, R. M. Ferreyra, A. Mugridge, A. R. Chaves and R. H. Mascheroni, "Quality of Brussels Sprouts (Brassica oleracea L. gemmifera DC) as Affected by Blanching Method," Journal of Food Engineering, Vol. 80, No. 1, 2007, pp. 218-225. doi:10.1016/i.jfoodeng.2006.02.049

[18] D. F. Olivera, S. Z. Viña, C. M. Marani, R. M. Ferreyra, A. Mugridge, A. R. Chaves and R. H. Mascheroni, "Effect of Blanching on the Quality of Brussels Sprouts (Brassica oleracea L. gemmifera DC) after Frozen Storage," Journal of Food Engineering, Vol. 84, No. 1, 2008, pp. 148-155. doi:10.1016/j.jfoodeng.2007.05.005

[19] J. Blahovec, "Mechanics and Ttexture of Fruits and Vegetables," In: R. Dris, R. Niskanen and S. M. Jain, Eds., Crop Management and Postharvest Handling of Horticultural Products (Vol. II), Fruits and Vegetables, Science Publishers, Enfield, 2003, pp. 139-185.

[20] H. K. Lichtenthaler, "Chlorophylls and Carotenoids: Pigments of Photosynthetic Biomembranes," Methods in Enzymology, Vol. 148, 1987, pp. 350-382. doi:10.1016/0076-6879(87)48036-1

[21] P. Wimalasiri and R. B. H. Wills, "Simultaneous Analysis of Ascorbic Acid and Dehydroascorbic Acid in Fruit and Vegetables by High-Performance Liquid Chromatography," Journal of Chromatography, Vol. 256, 1983, pp. 368-371. doi:10.1016/S0021-9673(01)88253-4 
[22] S. Y. Ruiz de Maya and J. L. Muñuera, "Las Preferencias del Consumidor: Estudio de su Composición a Través del Análisis Conjunto," Estudios sobre consumo, No. 28, 1993, pp. 27-43.

[23] G. G. Zeinstra, M. A. Koelen, F. J. Kok and C. De Graaf, "Cognitive Development and Children's Perceptions of Fruit and Vegetables; a Qualitative Study," International Journal of Behavioral Nutrition and Physical Activity, Vol. 4, No. 1, 2007, p. 30. doi:10.1186/1479-5868-4-30

[24] E. M. Gonçalves, J. Pinheiro, M. Abreu, T. R. S. Brandão and C. L. M. Silva, "Modelling the Kinetics of Peroxidase Inactivation, Colour and Texture Changes of Pumpkin (Cucurbita maxima L.) during Blanching," Journal of Food Engineering, Vol. 81, No. 4, 2007, pp. 693-701. doi:10.1016/j.jfoodeng.2007.01.011

[25] I. Revilla and A. M. Vivar-Quintana, "Effect of Canning Process on Texture of Faba Beans (Vicia faba)," Food Chemistry, Vol. 106, No. 1, 2008, pp. 310-314. doi:10.1016/j.foodchem.2007.02.046

[26] L. C. Greve, K. A. Shackel, H. Ahmadi, R. N. Mc Ardle, J. R. Gohlke and J. M. Labavitch, "Impact of Heating on Carrot Firmness: Contribution of Cellular Tturgor," Journal of Agriculture and Food Chemistry, Vol. 42, No. 12, 1994, pp. 2896-2899. doi:10.1021/jf00048a047

[27] P. Nisha, R. S. Singhal and A. B. Pandit, "A Study on the Degradation Kinetics of Visual Green Colour in Spinach (Spinaccea oleracea L.) and the Effect of Salt Therein,"
Journal of Food Engineering, Vol. 64, No. 1, 2004, pp. 135-142. doi:10.1016/j.jfoodeng.2003.09.021

[28] K. Higashi-Okai, S. Otani and Y. Okai, "Potent Suppressive Effect of a Japanese Edible Seaweed, Enteromorpha Prolifera (Sujiao-nori) on Initiation and Promotion Phases of Chemically Induced Mouse Skin Tumorigenesis," Cancer Letters, Vol. 140, No. 1-2, 1999, pp.21-25. doi:10.1016/S0304-3835(99)00047-6

[29] L. Ma and D. Dolphin, "The Metabolites of Dietary Chlorophylls," Phytochemistry, Vol. 50, No. 2, 1999, pp. 195-202. doi:10.1016/S0031-9422(98)00584-6

[30] K. Morita, M. Ogata and T. Hasegawa, "Chlorophyll Derived from Chlorella Inhibits Dioxin Excretion in Rats," Environmental Health Perspectives, Vol. 109, No. 3, 2001, pp. 289-294. doi:10.1289/ehp.01109289

[31] A. Podsędek, D. Sosnowska, M. Redzynia and B. Anders, "Antioxidant Capacity and Content of Brassica Oleracea Dietary Antioxidants," International Journal of Food Science and Technology, Vol. 41, Supplement 1, 2006, pp. 49-58. doi:10.1111/j.1365-2621.2006.01260.x

[32] S. M. Castro J. A. Saraiva, J. A. Lopes-da-Silva, I. Delgadillo, A. Van Loey, C. Smout and M. Hendrickx, "Effect of Thermal Blanching and of High Pressure Treatments on Sweet Green and Red Bell Pepper Fruits (Capsicum annuum L.)," Food Chemistry, Vol. 107, No. 4, 2008, pp. 1436-1449. doi:10.1016/i.foodchem.2007.09.074 